\title{
The International Tax Competitiveness: Bibliometric Analysis
}

http://doi.org/10.21272/fmir.5(1).126-138.2021

Oleksiy Mazurenko, ORCID: https://orcid.org/0000-0001-5925-3692

Deputy Head of the Main Department of the State Tax Service of Ukraine in Sumy region, PhD student, Sumy State University, Ukraine

Inna Tiutiunyk, ORCID: https://orcid.org/0000-0001-5883-2940

Doctor of Economics, Associate Professor, Sumy State University, Ukraine

\begin{abstract}
This paper summarizes the arguments and counterarguments within the scientific discussion on the generalization of the main vectors of the tax competitiveness theory's development. The main purpose of the article is to analyze and systematize the research of scientists on the formation of tax competitiveness of the country, to identify the relationship of tax competitiveness with other economic categories, to determine the most promising areas of research on this issue. The results of trend analysis of scientific publications on tax competitiveness, indexed by Scopus and Web of Science scientometric databases, show a gradual increase in the relevance of these issues. The average growth rate of the number of publications on tax competitiveness in the Scopus database exceeds $12 \%$, and in the Web of Science database $-45 \%$. The methodological tools of the bibliometric analysis are VOSViewer v.1.6.10 and Scopus and Web of Science database analysis tools. The object of analysis is 4,598 publications indexed in the Web of Science database and 4,898 publications indexed in the Scopus database. The issues of international tax competitiveness became most relevant in 2003-2005, which coincided with the period of aggravation of the global economic crisis, which was accompanied by a significant reduction in tax revenues to budgets. The article identifies the top 10 Journals, most of which are indexed simultaneously by two databases and are part of the first quarter, in which the issue of tax competitiveness was considered most often. The study empirically confirms and theoretically proves the intersectoral nature of the study of the problem of the country's tax competitiveness. According to the Web of Science database, issues of tax competitiveness were most often considered within the subject areas of Economics (39\% of publications); Business Finance (6\%); Environmental Studies (6\%); Political Science (5\%); Law (4\%); Urban Studies (3\%); Business (3\%); Management (3\%); Environmental Sciences (2\%); Public Administration (2\%); Regional Urban Planning (2\%); International Relations (2\%); Operations Research Management Science 2\%) and others (21\%), while according to the Scopus database - Economics, Econometrics and Finance (published 28\% of all papers); Social Sciences (21\%); Business, Management and Accounting (13\%); Engineering (7\%); Environmental Science (7\%); Medicine (5\%); Energy (4\%); Computer Science (2\%); Arts and Humanities (2\%); Decision Sciences (2\%); Earth and Planetary Sciences (1\%); Materials Science (1\%); Agricultural and Biological Sciences (1\%); Others (6\%). The paper clusters international research networks on tax competitiveness by geographical area and identifies 5 clusters of cooperation of scientists in the preparation of publications indexed in the Web of Science database and 4 clusters - in the preparation of publications indexed in the Scopus database. According to the results of the analysis of metadata of publications devoted to the tax competitiveness, 14672 keywords, the frequency of use of which exceeds 5, were identified and grouped into 5 patterns. Most often, the concept of tax competitiveness is associated with the concepts of tax, economics, competition, costs, taxation.
\end{abstract}

Keywords: bibliometric analysis, cluster, economic development, tax burden, tax competitiveness, visualization.

JEL Classification: H20, H71, F38.

Cite as: Mazurenko, O., Tiutiunyk, I. (2021). The International Tax Competitiveness: Bibliometric Analysis. Financial Markets, Institutions and Risks, 5(1), 126-138. http://doi.org/10.21272/fmir.5(1).126-138.2021

Received: 20 January 2020

Accepted: 25 February 2021

Published: 30 March 2021

Copyright: (C) 2021 by the authors. Licensee Sumy State University, Ukraine. This article is an open access article distributed under the terms and conditions of the Creative Commons Attribution (CC BY) license (https://creativecommons.org/licenses/by/4.0/) 


\section{Introduction}

One of the factors that has a significant impact on the country's economic development is the level of its tax competitiveness. Given the shortage of financial resources, tax competitiveness is a factor that determines the level of the favorable business environment in the country, its attractiveness for business registration and operations in the area. Quite often, the level of the tax burden is seen by governments as an effective tool to improve their position in the competition for more favorable conditions for doing business. At the same time, the level of tax competitiveness of the country is an indicator of the quality of its investment environment and therefore is taken into account by investors when deciding on the feasibility of investing in the country's economy. Thus, a more comprehensive study of this concept, the analysis of its relationship with other economic categories is an important component of increasing the level of economic development of the country.

\section{Literature Review}

Tax competitiveness is a complex concept that, depending on the goals of economic entities, can take various forms and be accompanied by a wide range of tools to achieve it.

Tiebout (1956) links the concept of tax competitiveness to the tax autonomy of local governments. It is the presence of tax autonomy that allows local governments to compete for the right to register a business on their territory by manipulating the size of tax rates and fees, the introduction of preferential tax regimes. This tax competition has a positive economic effect on local budgets and the economic growth of these countries. Thus, the author understood tax competition as the process of reducing the level of the tax burden on local governments in their territories.

A similar view was held by Bradford and Oates (1971). At the same time, the authors stressed that these manifestations of tax competition, along with economic benefits, have many negative consequences. According to the authors, these actions of public authorities lead to their inability to provide the population with a sufficient level of public goods.

Some scholars have viewed tax competition as a prerequisite for economic growth and profit maximization (Genschel \& Schwarz, 2011; Ludema \& Wooton, 2000; Tiutiunyk \& Kobushko, 2018). Some tax-competitive jurisdictions receive economic benefits by creating opportunities for higher profits, subject to the registration of firms in the area. Ultimately, this leads to a significant increase in the tax burden in these areas and the loss of competitive position in the country (Ludema and Wooton; Baldwin and P. Krugman).

\section{Methodology and research methods}

The main hypothesis of this study is the assumption of a steady increase in the relevance of tax competitiveness and analysis of the trend of changes in the number of scientific publications on this issue in journals indexed by scientific databases. The hypothesis put forward in the work will be tested in the following sequence:

1. Trend analysis of the dynamics of change in the number of publications devoted to the study of the concept of "tax competitiveness".

2. Separation of patterns by frequency of use in publications of the phrase "tax competitiveness".

3. Clustering of major research networks by geographical area.

The object of the article is publications in journals indexed in Scopus and Web of Science databases.

The analysis of publications indexed by these databases found 4,598 publications indexed in the Web of Science database and 4,898 publications indexed in the Scopus database.

The analysis of the frequency of research on the problem of the formation of tax competitiveness showed a significant increase in interest in these issues over the past 20 years. At the same time, a time sample of 19272020 from the WoS database and 1970-2020 from the Scopus database was used to test the validity of the hypothesis.

\section{Results}

The results of the trend analysis of the number of publications devoted to these issues in the Scopus and Web of Science databases shown in Figure 1 show a gradual increase in the relevance of these issues. 
Until 1990, the level of research on these issues was at the same level. Only since 1991 has there been an increase in the number of publications indexed by Scopus (average rate over 12\%) and Web of Science databases (over 45\%). The most acute aspects of tax competitiveness began to be studied in 2003-2005. One of the reasons for this situation is the global economic crisis, which was accompanied by a significant reduction in tax revenues to budgets and, consequently, the escalation of the search for alternative mechanisms to increase the tax competitiveness of countries.

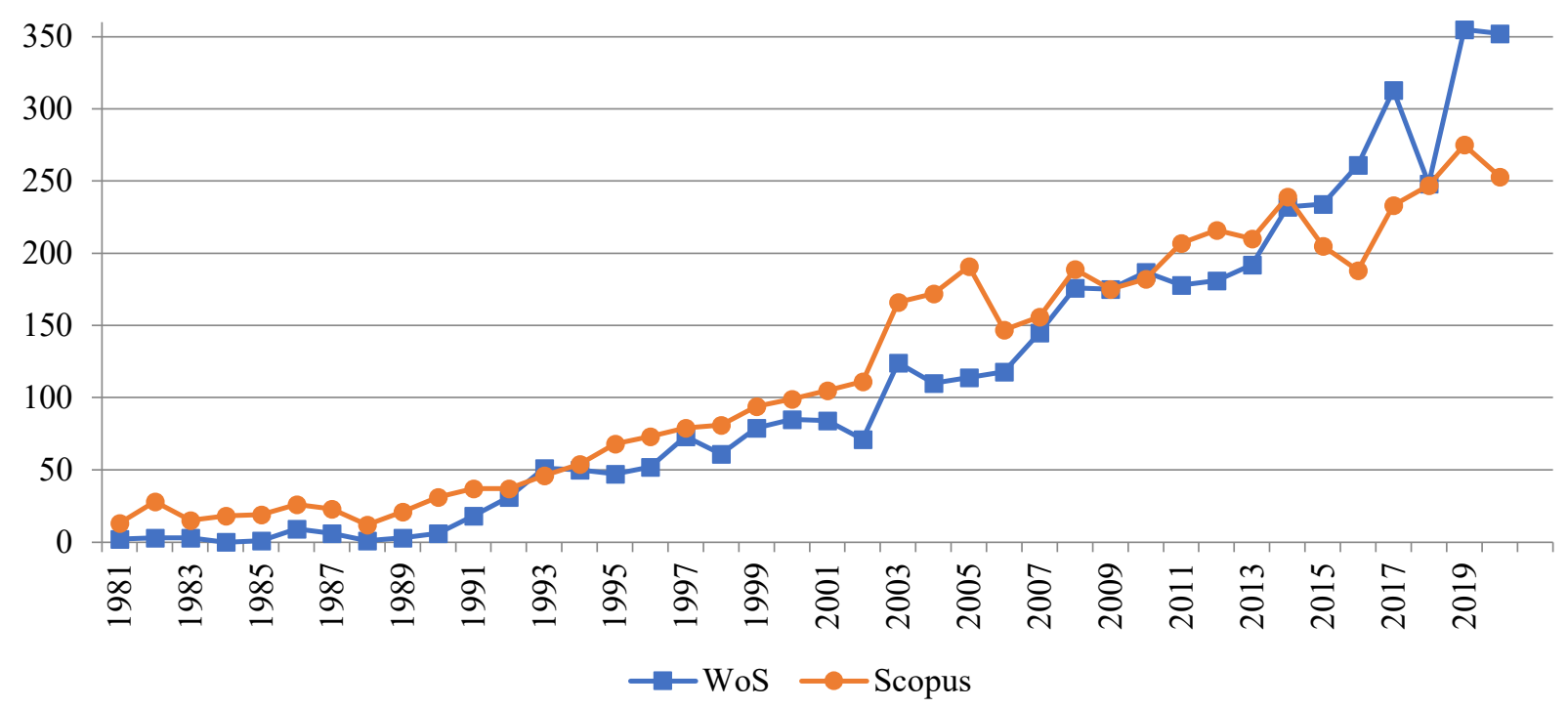

Figure 1. The trend of changes in the number of publications on tax competitiveness in Scopus and Web of Science databases. Sources: Compiled by the authors using data from Scopus and WoS.

Thus, the results suggest that the problem of tax competitiveness is not new to economic theory, and its formation occurs in 2003-2005.

At the next stage, we will conduct a bibliographic analysis of the concept of "tax competitiveness" using VOSViewer v.1.6.10 tools. The generalization of scientific publications in which the results of the study of tax competitiveness were published allowed to determine The top 10 Journals, in which the issue of tax competitiveness was considered most often (Table 1).

Table 1. The top 10 Scientific Journals, indexed by Scopus/Web of Science, which published the papers on tax competition

\begin{tabular}{|c|c|c|c|}
\hline \multirow{2}{*}{ Source title } & \multicolumn{2}{|c|}{ Number of the papers } & \multirow{2}{*}{ Quartile } \\
\hline & Web of Science & Scopus & \\
\hline International Tax and Public Finance & 210 & 171 & Q1 \\
\hline Journal of Public Economic & 207 & 143 & Q1 \\
\hline Regional Science and Urban Economics & 112 & 75 & Q1 \\
\hline Journal of Urban Economics & 91 & 57 & Q1 \\
\hline National Tax Journal & 83 & - & Q2 \\
\hline Journal of Public Economic Theory & 58 & - & Q1 \\
\hline Public Choice & 53 & 39 & Q1 \\
\hline European Economic Review & 51 & 40 & Q1 \\
\hline Environmental and Resource Economics & 48 & 40 & Q1 \\
\hline Finanzarchiv & 46 & - & Q3 \\
\hline Energy Policy & - & 49 & Q1 \\
\hline Public Finance Review & - & 48 & Q3 \\
\hline Journal of Public Economic Theory & - & 44 & Q1 \\
\hline
\end{tabular}

Sources: Compiled by the authors using the Scopus and Web of Science data.

Most of the articles were published in journals indexed simultaneously by two databases and included in the first quarter. The publication of scientific papers devoted to the study of tax competition in high-ranking journals testifies to the high relevance of these issues and the practical value of the results for the world community. At the same time, the analysis shows the cross-sectoral nature of the study of these issues. In addition to social and economic fields of knowledge, these issues are explored in other subject areas. Thus, according to the Web of Science database, tax competitiveness was most often considered within the following subject areas: 
Economics (39\% of publications); Business Finance (6\%); Environmental Studies (6\%); Political Science (5\%); Law (4\%); Urban Studies (3\%); Business (3\%); Management (3\%); Environmental Sciences (2\%); Public Administration (2\%); Regional Urban Planning (2\%); International Relations (2\%); Operations Research Management Science 2\%) and others (21\%).

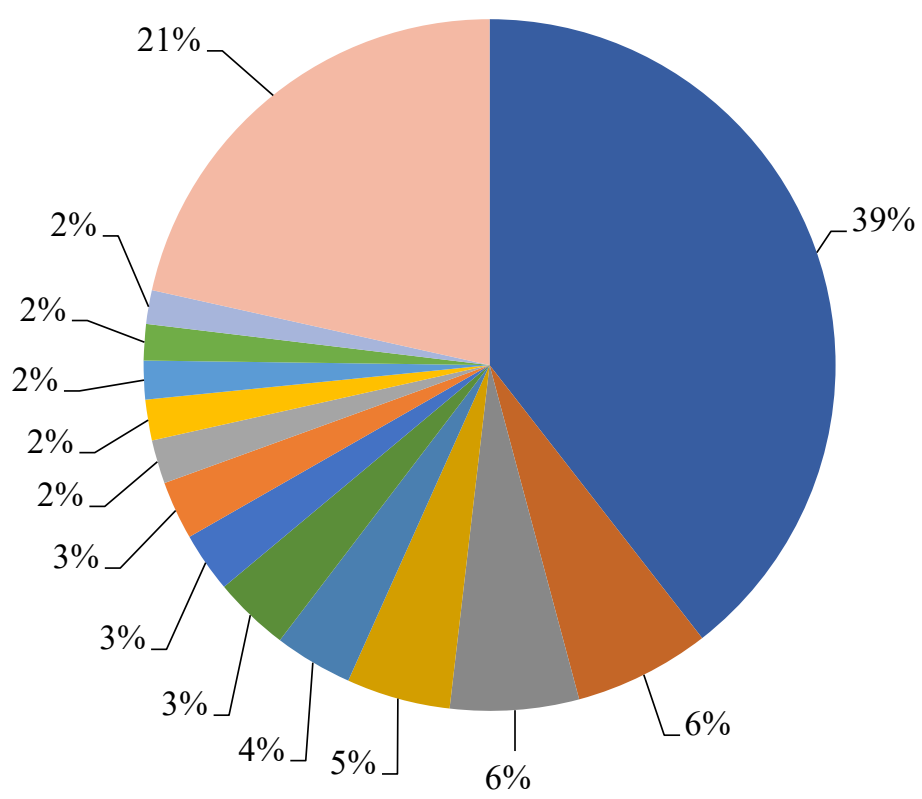

\author{
Economics \\ - Business Finance \\ Environmental Studies \\ - Political Science \\ - Law \\ - Urban Studies \\ Business \\ Management \\ Environmental Sciences \\ Public Administration \\ - Regional Urban Planning \\ - International Relations \\ Operations Research Management \\ Science
}

Figure 2. Distribution of publications indexed in the Web of Science database by fields of knowledge

Sources: Compiled by the authors using the Scopus and Web of Science data.

According to the Scopus database, $28 \%$ of all papers were published within the subject area of Economics, Econometrics and Finance; Social Sciences - 21\%; Business, Management and Accounting - 13\%; Engineering - 7\%; Environmental Science - 7\%; Medicine - 5\%; Energy - 4\%; Computer Science - 2\%; Arts and Humanities - 2\%; Decision Sciences - 2\%; Earth and Planetary Sciences - 1\%; Materials Science - 1\%; Agricultural and Biological Sciences - 1\%; Others - 6\%.

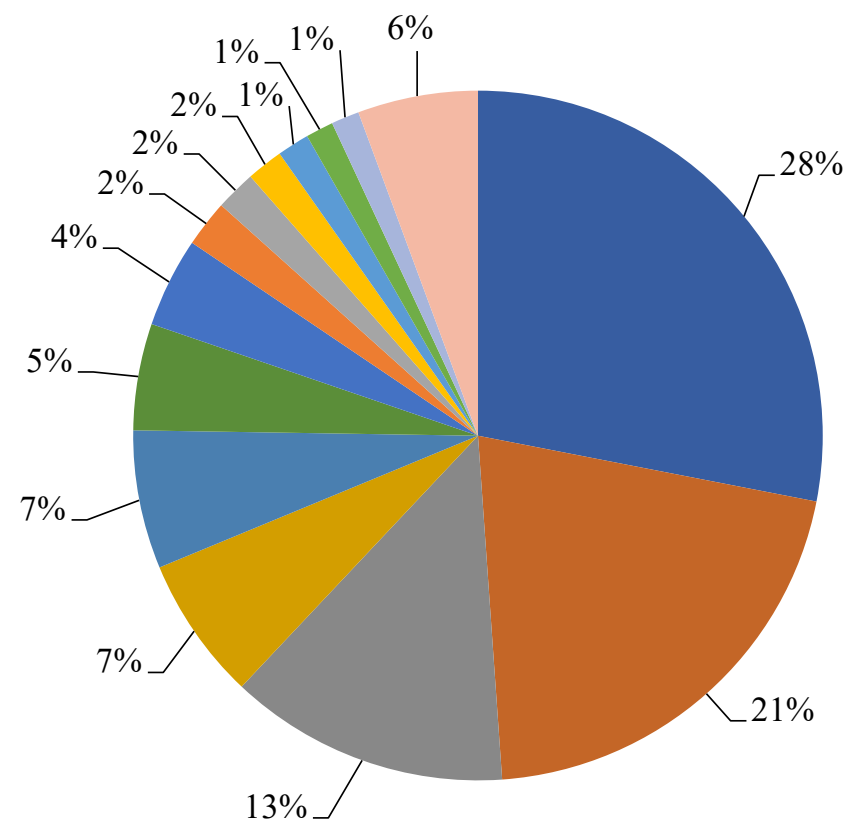

\author{
Economics, Econometrics and \\ Finance \\ - Social Sciences \\ Business, Management and \\ Accounting
Engineering \\ Environmental Science \\ - Medicine \\ Energy \\ - Computer Science \\ Arts and Humanities \\ Decision Sciences \\ Earth and Planetary Sciences \\ Materials Science \\ Agricultural and Biological \\ Sciences
}

Figure 3. Distribution of publications indexed in the Scopus database by fields of knowledge

Sources: Compiled by the authors using the Scopus and Web of Science data 
Analysis of publications by geographical area (Fig. 4) allows us to identify clusters of international research networks on tax competitiveness. The largest number of papers on tax competitiveness were published by scientists from the US, Germany, UK, China, Canada and Japan. In China, Romania and Turkey publications on tax competitiveness appeared only since 2016 (Table 2).

Table 2 . Top 20 countries by number of scientific publications

\begin{tabular}{|c|c|c|c|c|c|}
\hline \multirow{2}{*}{ Country } & \multicolumn{2}{|c|}{ Number of the papers } & \multirow{2}{*}{ Country } & \multicolumn{2}{|c|}{ Number of the papers } \\
\hline & Web of Science & Scopus & & Web of Science & Scopus \\
\hline USA & 1402 & 1373 & Belgium & 132 & 121 \\
\hline Germany & 593 & 520 & Australia & 113 & 126 \\
\hline England & 414 & 412 & Norway & 85 & 76 \\
\hline China & 386 & 285 & Taiwan & 79 & 67 \\
\hline Canada & 234 & 198 & Sweden & 76 & 78 \\
\hline Japan & 234 & 205 & South korea & 74 & 64 \\
\hline France & 227 & 211 & Denmark & 72 & 56 \\
\hline Italy & 188 & 129 & Romania & 65 & - \\
\hline Spain & 137 & 102 & Russia & 64 & - \\
\hline Netherlands & 136 & 105 & India & - & 71 \\
\hline Switzerland & 135 & 120 & Russian Federation & - & 70 \\
\hline
\end{tabular}

Sources: Compiled by the authors using the Scopus and Web of Science data.

The study of international cooperation of scientists allows identifying 5 clusters of cooperation of scientists in the preparation of publications, indexed in the Web of Science database, in particular: cluster 1 - USA, Japan, Taiwan, Italy; cluster 2 - the USA, Turkey, Portugal, Belgium, Greece, Cyprus, Hungary, South Africa; cluster 3 - USA, Spain, Iran, South Korea; cluster 4 - Czech Republic, Romania, Indonesia, Netherlands, USA; cluster 5 - Germany, Switzerland, Canada, Norway and the 4 largest clusters in the preparation of publications indexed in the Scopus database, in particular: cluster 1 - the USA, Mexico City, Italy, Turkey, Germany, Spain, Belgium, Austria; cluster 2 - Denmark, Austria, Czech Republic, Romania, Italy, Iran, Great Britain, Germany, USA, China; cluster 3 - Germany, Spain, Norway, Belgium, Great Britain, the USA, China, Japan, the Netherlands; cluster 4 - Great Britain, Portugal, South Africa, New Zealand, Cyprus, Greece.

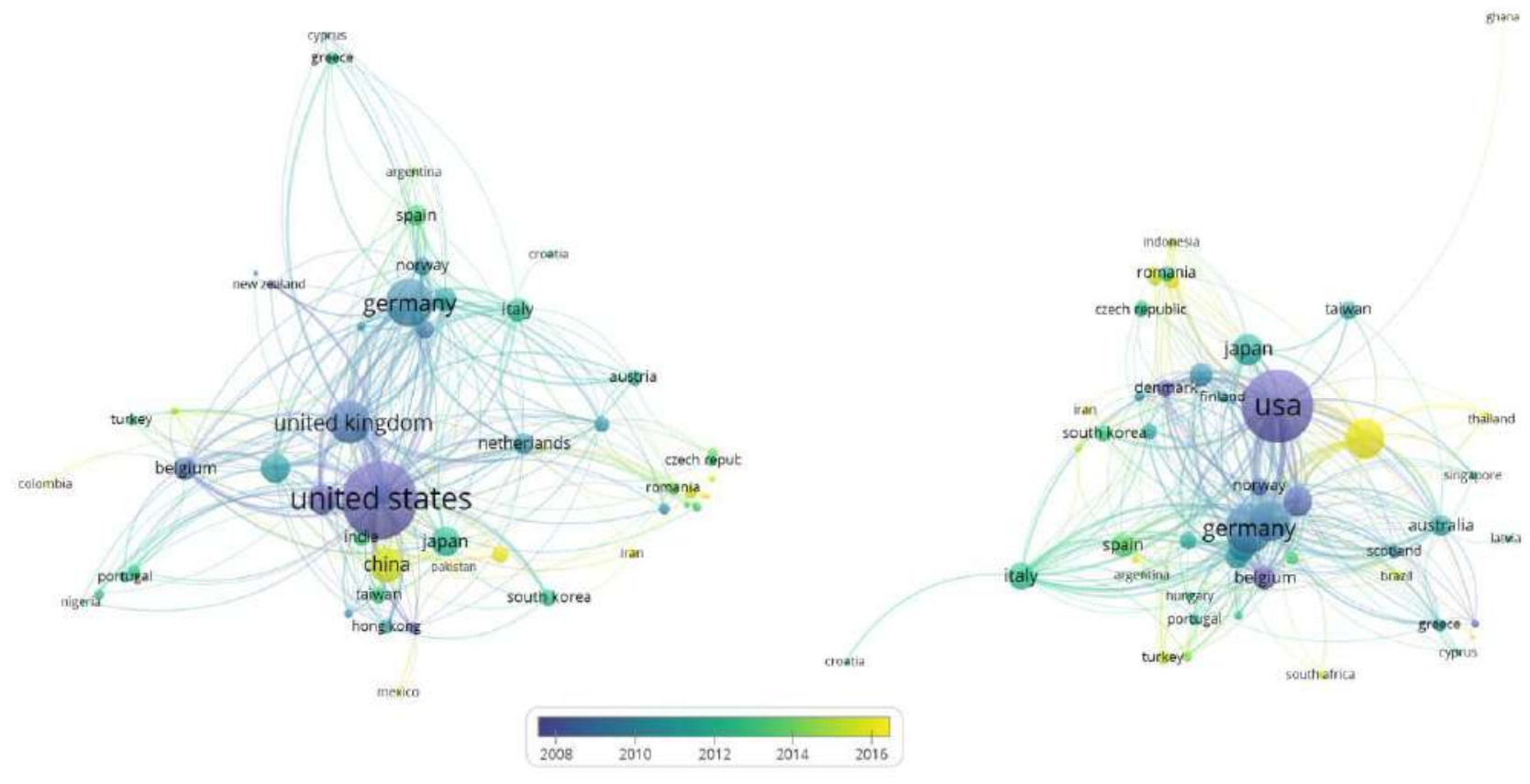

a) Scopus

b) Web of Science

Figure 4. Clusters of international research networks on tax competitiveness by geographical area

Sources: Compiled by the authors using data from Scopus and WoS by VOSviewer tool

Visualization of the network of the most cited authors of publications on tax competitiveness has shown the presence of a significant number of scholars who are interested in these issues. J. Wilson, M. Keen, S. Lahird, C. Radaeli, H. Cremer, C. Fuest, W. Eggert were the first to study these questions. Since 2015, these issues have been studied by T. Matsumura, O. Hikaru, I. Wooton, H. Ogawa, P. Pieretti and others. 


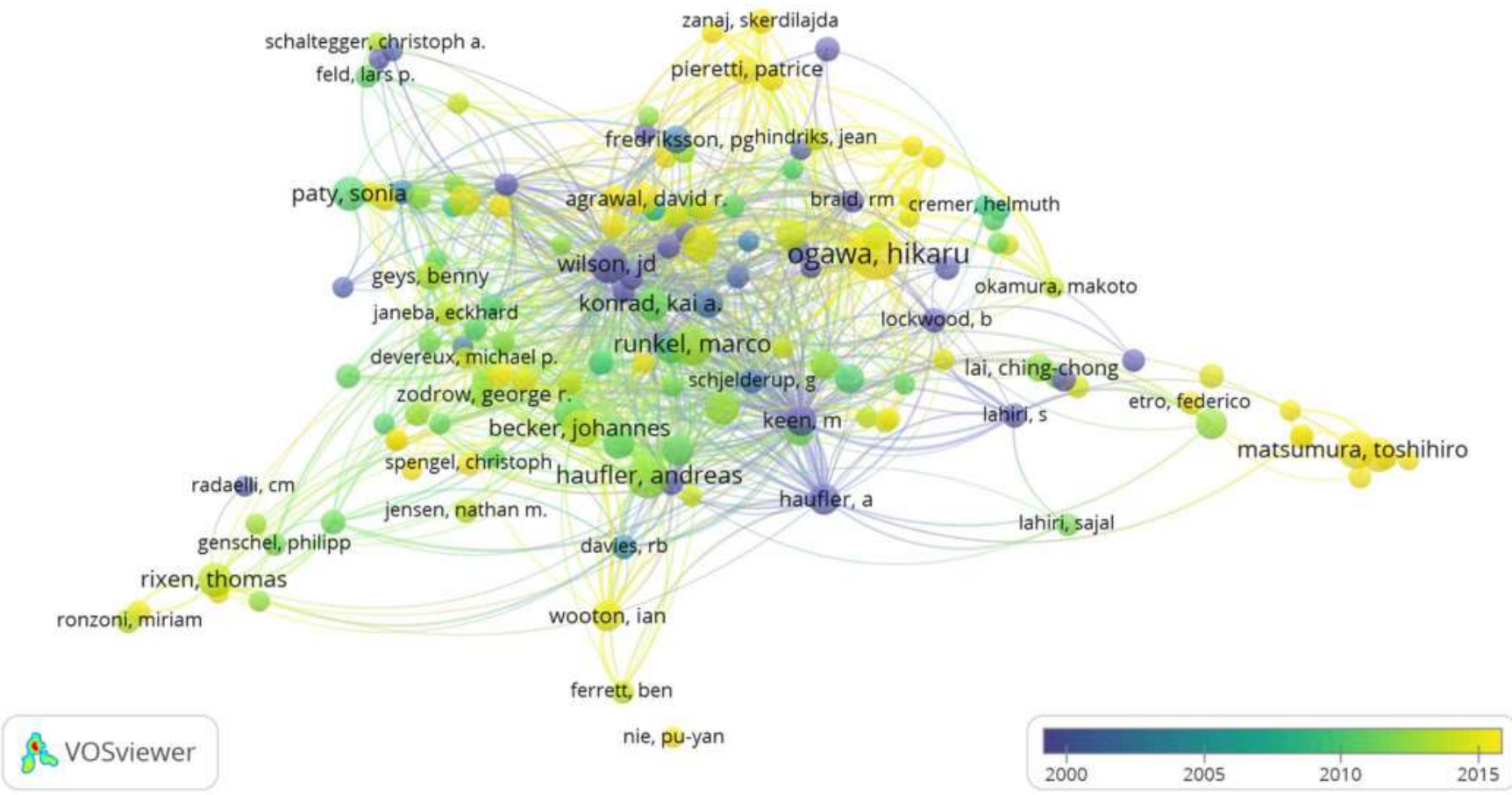

a) Web of Science

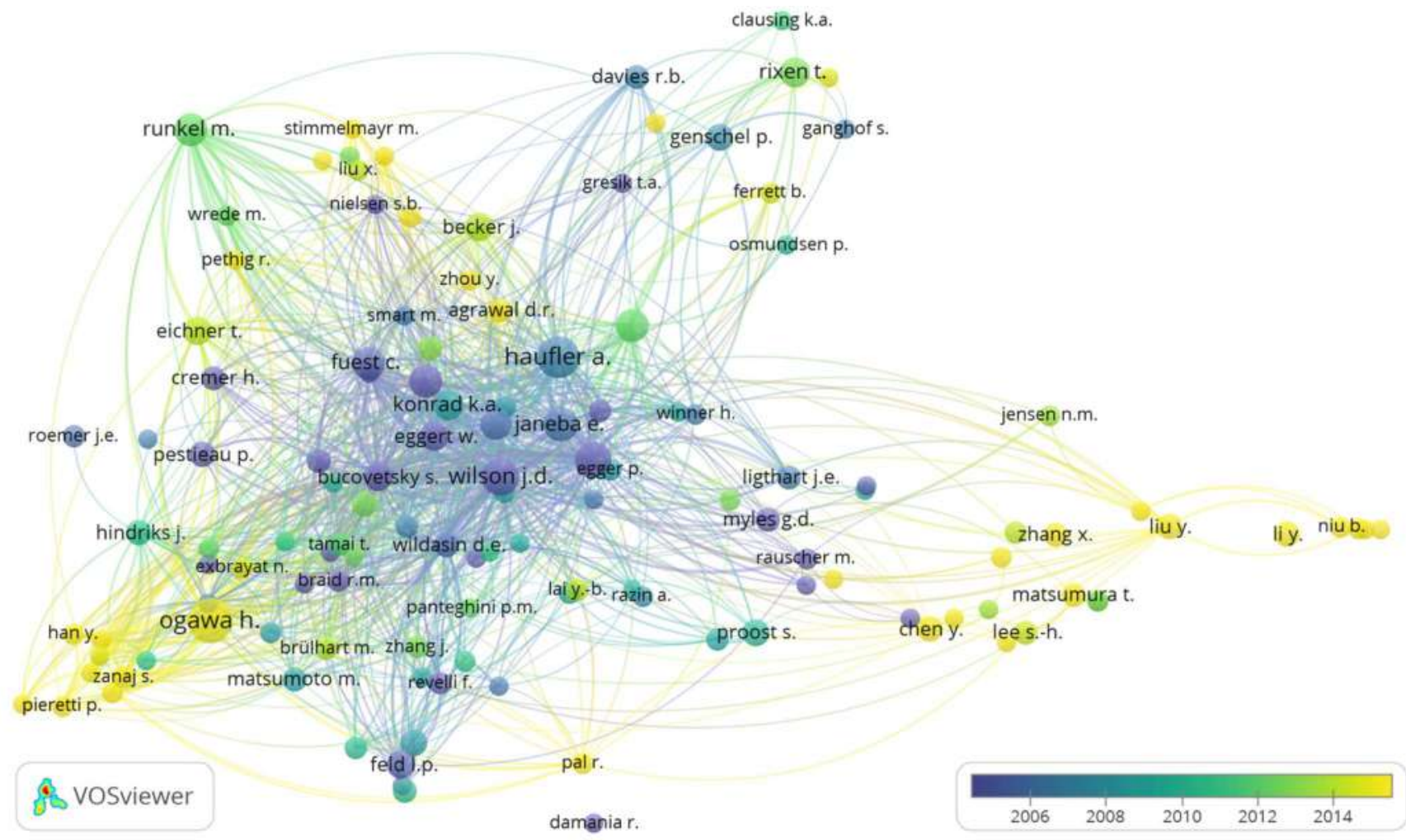

b) Scopus

Figure 5. Visualization of the network of the most cited authors of publications on tax competitiveness

Sources: Compiled by the authors using data from Scopus and WoS by VOSviewer tool

According to the results of the analysis of metadata of publications devoted to the study of tax competitiveness (title of the publication, annotation, keywords of the author) 14672 keywords were identified (frequency of use exceeds 5) and grouped into 5 patterns (Fig. 6). Most often, the concept of tax competitiveness is associated with the concepts of tax, economics, competition, costs, taxation.

The size of the circle reflects the frequency of use of this term along with the concept of "tax competitiveness". 


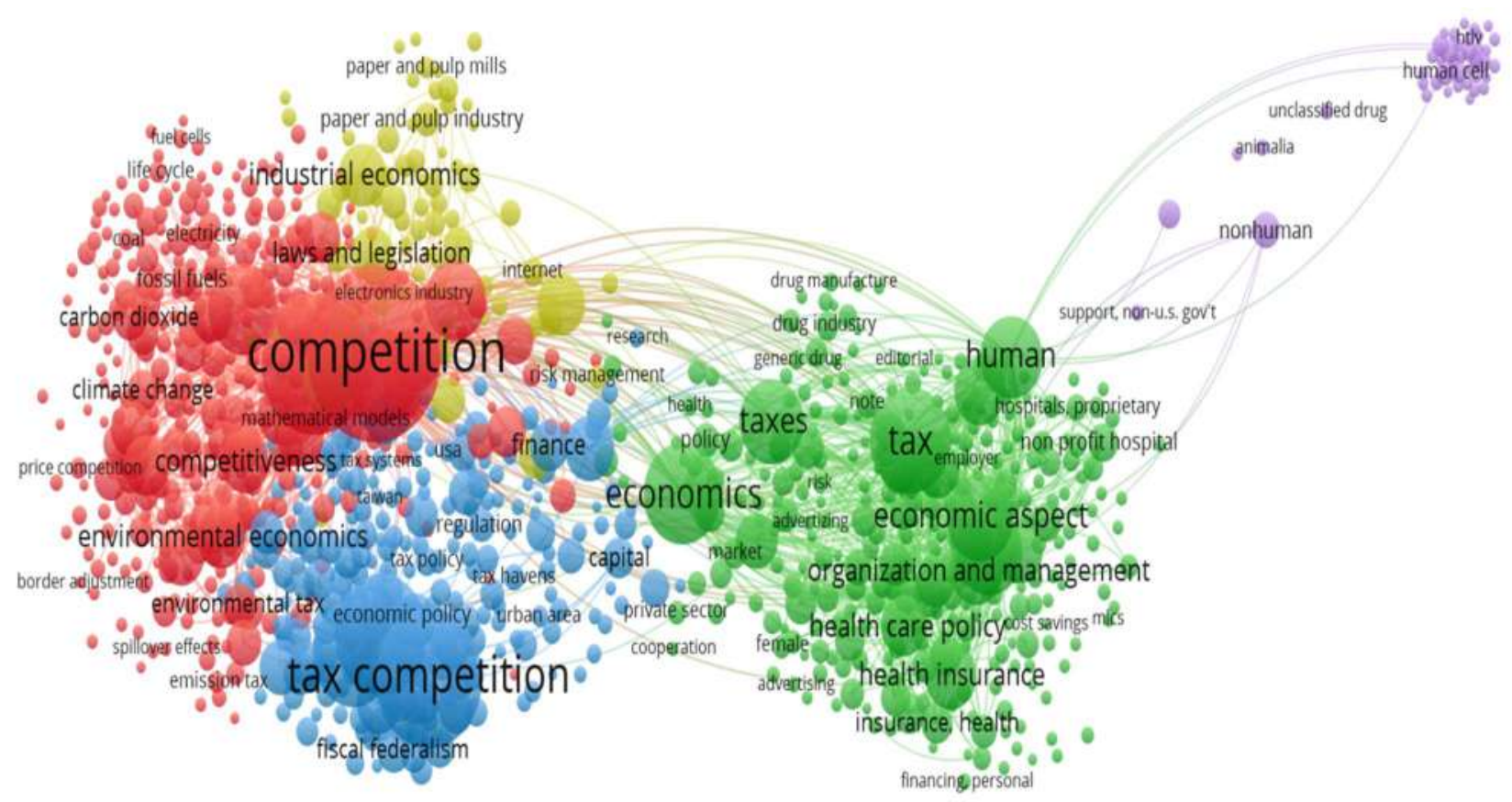

Figure 6. Visualization of patterns in terms of citations of publications on tax competitiveness

Sources: Compiled by the authors using data from Scopus and WoS by VOSviewer tool

Within the red pattern (872 links) tax competitiveness is studied in connection with the following keywords: investments, costs, industry, profitability, environmental economics, industrial competitiveness, decision making, externalities, economic analysis, climate change, tax credits, life cycle, carbon, climate policy (Fig. 7, see in Appendix).

Within the second largest green pattern (559 links) the following keywords are used: economic competition, economic aspect, tax, tax exemption, ownership, social welfare, government (Fig. 10, see in Appendix).

The following keywords are used within the yellow pattern (301 links): industrial economics, regulatory compliance, economic conditions, contracts, strategic planning, tariffs, wages, taxes and legislation, cost effectiveness, mergers and acquisitions, risk assessment (Figure 8, see in Appendix).

The blue pattern is characterized by the use of the following keywords: fiscal policy, fiscal federalism, optimal taxation, imperfect competition, monopoly, tax burden, income, policy making, regulation, subsidies, tax intensive, tax reform, market conditions (Figure 9, see in Appendix).

The smallest pattern (150 links) combines publications containing the following keywords: nonhuman, controlled study, tax protein, base sequence, metabolism, unclassified drug (Fig. 10, see in Appendix).

The grouping of scientific publications on tax competitiveness by keywords is the basis for further study of this concept within each of the identified patterns.

\section{Conclusions}

The results of the bibliometric analysis proved the significant relevance and popularity of issues related to the study of tax competitiveness. The first single publications on these issues were contacted in early 1981. Every year there is a steady increase in the number of publications on these issues. One of the reasons for this growth was the global economic crisis, which was accompanied by an aggravation of the economic situation, budget deficits, declining budget revenues, and more. The clustering of research networks by geographical area has confirmed the high level of cooperation of scientists from different countries. The vast majority of publications are international in nature.

Author Contributions: conceptualization, Mazurenko, O., Tiutiunyk, I.; data curation, Mazurenko, O.; formal analysis, Mazurenko, O.; funding acquisition, Mazurenko, O.; investigation, Mazurenko, O.; methodology, Mazurenko, O.; project administration, Mazurenko, O.; resources, Mazurenko, O.; software, Mazurenko, O.; 
supervision, Mazurenko, O., Tiutiunyk, I.; validation, Tiutiunyk, I.; visualisation, Tiutiunyk, I.; writing - original draft, Mazurenko, O., Tiutiunyk, I.; writing- review and editing, Mazurenko, O., Tiutiunyk, I.

Funding. This research was funded solely by the authors.

\section{References}

1. Baldwin, R. E. \& Krugman, P. (2004). Agglomeration, Integration and Tax Harmonization. European Economic Review, 48, 1-23. Retrieved from: https://econpapers.repec.org/article/eeeeecrev/v 3a48_3ay 3a2004 3ai 3a1 3ap 3a1-23.htm

2. Boiko, A., Samusevych, I. (2017). The role of tax competition between the countries of the world and the features of determining the main tax competitors of Ukraine among the European countries. Financial Markets, Institutions and Risks, 1(1), 72-79. http://doi.org/10.21272/fmir.1(1).72-79.2017

3. Bradford, D., \& Oates, W. (1971). The Analysis of Revenue Sharing in a New Approach to Collective Fiscal Decisions. Quarterly Journal of Economics, 85(3), 416-439. Retrieved from: https://econpapers.repec.org/article/oupqjecon/v 3a85 3ay 3a1971 3ai 3a3 3ap 3a416-439..htm

4. Eddassi, H. (2020). Fiscal Regime and Tax Policy in Resource-Rich Countries In The Process Of Globalization: Literature Review. SocioEconomic Challenges, 4(2), 67-77. https://doi.org/10.21272/ sec.4(2).67$\underline{77.2020}$

5. Genschel, P., \& Schwarz, P. (2011). Tax Competition: A Literature Review. Socio-Economic Review, 9, 339-370. https://doi.org/10.1093/ser/mwr004

6. Ludema, R., \& Wooton, I. (2000). Economic Geography and the Fiscal Effects of Regional Integration. Journal of International Economics, 52(2), 331-357.

7. Mazloumfard H., Glantz V. (2017). The influence of tax burden on the profit of banks in conditions of monopolistic competition: economic-mathematical modeling. Financial Markets, Institutions and Risks, 1(4), 2836. http://doi.org/10.21272/fmir.1(4).28-36.2017

8. Miller, A.D. (2019). Current Mining Taxation Policy Implemented by both Mongolia and Kazakhstan: The Development Comparatives between Ulaanbaatar and Astana. Business Ethics and Leadership, 3(2), 39-52. http://doi.org/10.21272/bel.3(2).39-52.2019

9. Mukherjee, S. (2018). Cross Country Tax Competition and its Impact on Multinational Corporations - a Theoretical Re-examination. Financial Markets, Institutions and Risks, 2(1), 97-104. http://doi.org/10.21272/fmir.2(1).97-104.2018

10. S. Nisa, M.S. Kavya. (2018). An Evaluation of Financial Management System in Gulati Institute of Finance and Taxation an Autonomous Institution, Thiruvananthapuram, Kerala. Financial Markets, Institutions and Risks, 2(2), 40-57. http://doi.org/10.21272/fmir.2(2).40-57.2018

11. Samusevych I., Shamaelh, A. (2017). The Relationship Between the Tax Burden and Financing Public Services: A Comparison of Ukraine and European Countries. Financial Markets, Institutions and Risks, 1(3), 5564. http://doi.org/10.21272/fmir.1(3).55-64.2017

12. Singh, S. N. (2019). The Analysis of Value Added Tax (Vat) to Increasing Government Revenue in Ethiopia. Financial Markets, Institutions and Risks, 3(2), 115-127. http://doi.org/10.21272/fmir.3(2).115$\underline{127.2019}$

13. Singh, S.N. (2019). Impact of Value Added Tax on Business Enterprises: A Case of Mettu Town. Financial Markets, Institutions and Risks, 3(4), 62-73. http://doi.org/10.21272/fmir.3(4).62-73.2019.

14. Tiebout, C. (1956). A Pure Theory of Local Expenditures. Journal of Political Economy, 64, 416. Retrieved from: https://www.jstor.org/stable/1826343?seq=1

15. Tiutiunyk, I. V., \& Kobushko Ia. V. (2018). Instruments for minimizing the tax burden in ukraine: comparative analysis and effects from application. Ekonomichnyy analiz, 28(4), 122-130. Retrieved from: http://sfs.gov.ua/en/ 
Appendix

fossil fuel pawer glants $\begin{aligned} & \text { solar energy electric vehicles } \\ & \text { biomass fuettax deregulation cost effectivenegss }\end{aligned}$

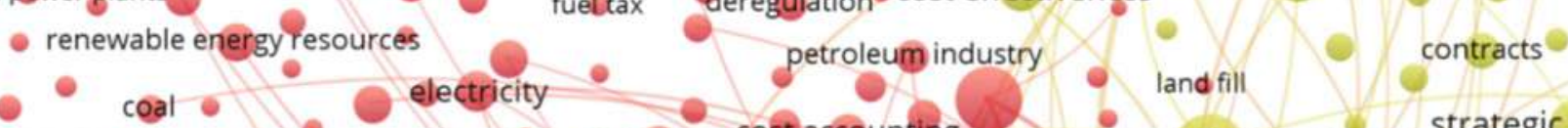

renewableenergiese electricutilities gasoline costaccounting laws and legislation strategic planning

feed-io tariff fossilfuels fuels. energy conservation technology taiffs internet

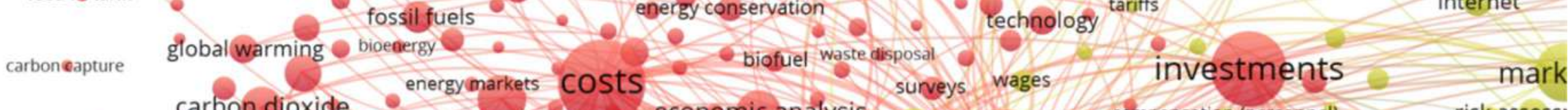
carbon dioxide economic analysis compensation(personnel) risk assesst

electricity prices greenhouse gases. fuel consumption timber - public utilities cost benefit analysis renewables energy efficiency alr pollution controlos competition inceative

manufacturing industriescost reduction fossil fuel energutaxes sweden

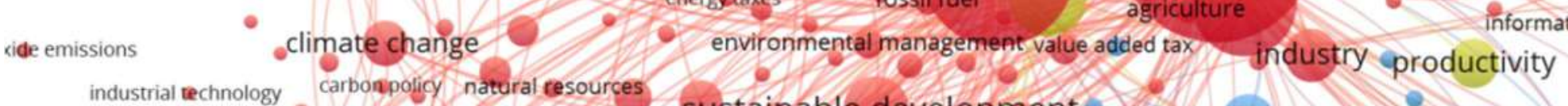

industrial technology carbongobicy natural cesources sustainable developments innovation

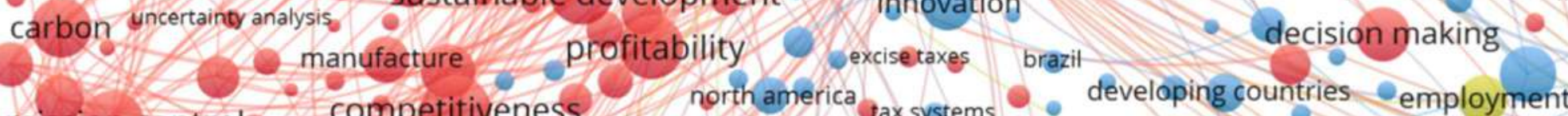

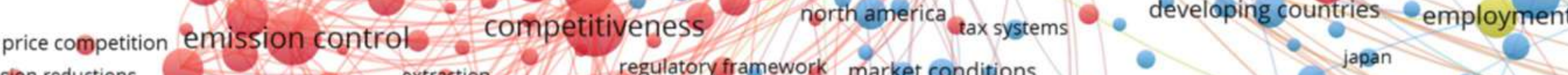

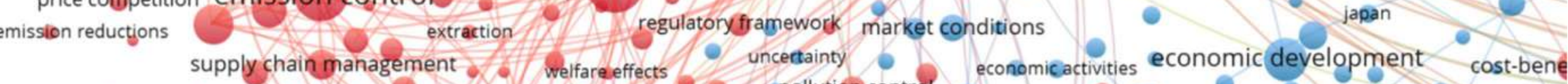
carborapricing - competitive markets game theory management science economic growth sub-saharan africa environmentaleconomics management science subsidies empetitive markets game theory gregulation privatization leakege dynamic game enviranmental economics taxincentive subsidies mobjlity sustainable supplychagins - pollution tax - policy implementation exporto moblity tax policy is VOSviewer border taxadjustments tariff structure modeling paneldata labormarket envirnnmental tax
Figure 7. The network visualisation of the co-citation of the keywords on red cluster trade transfer pricing poli 
ns

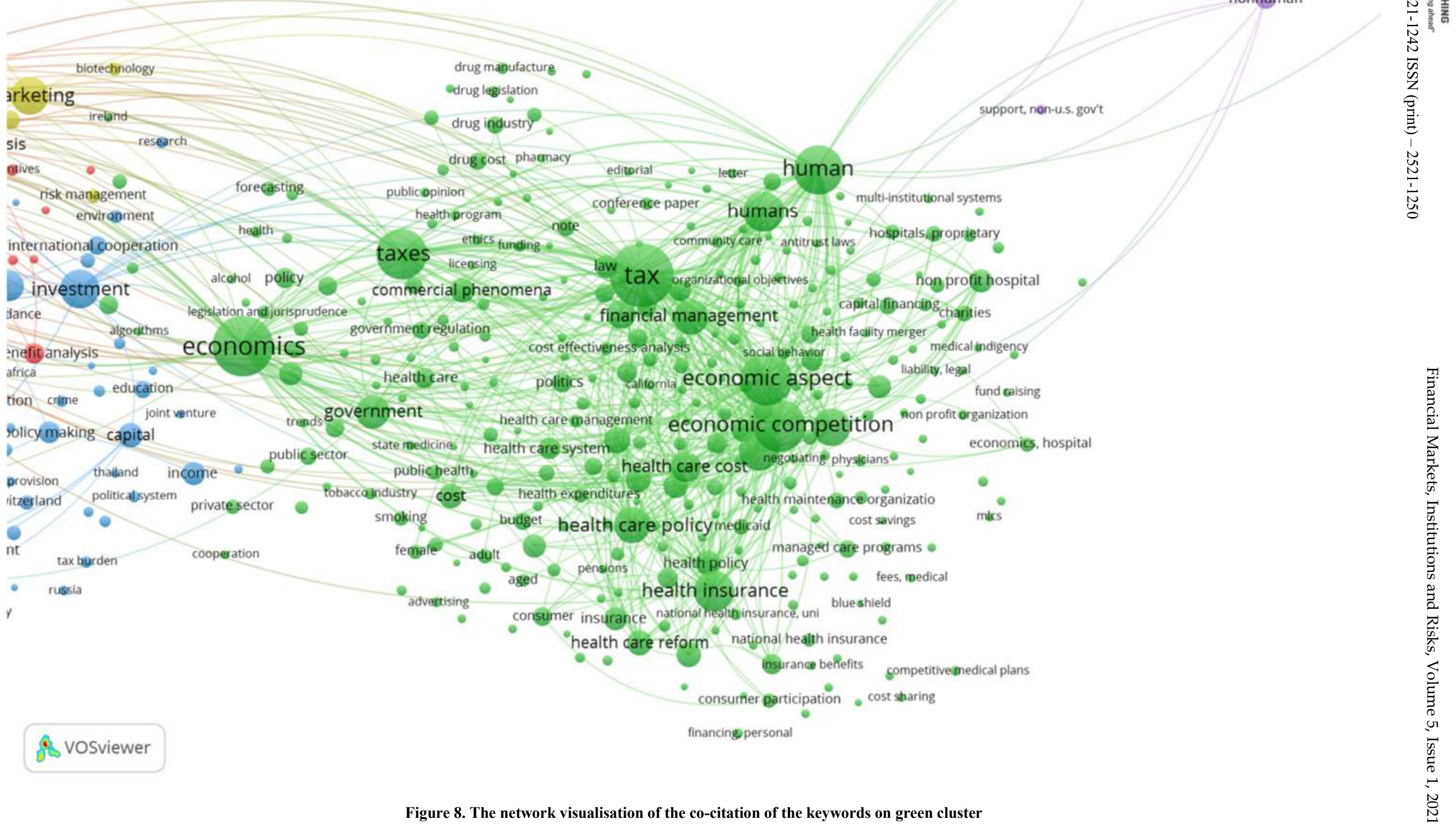




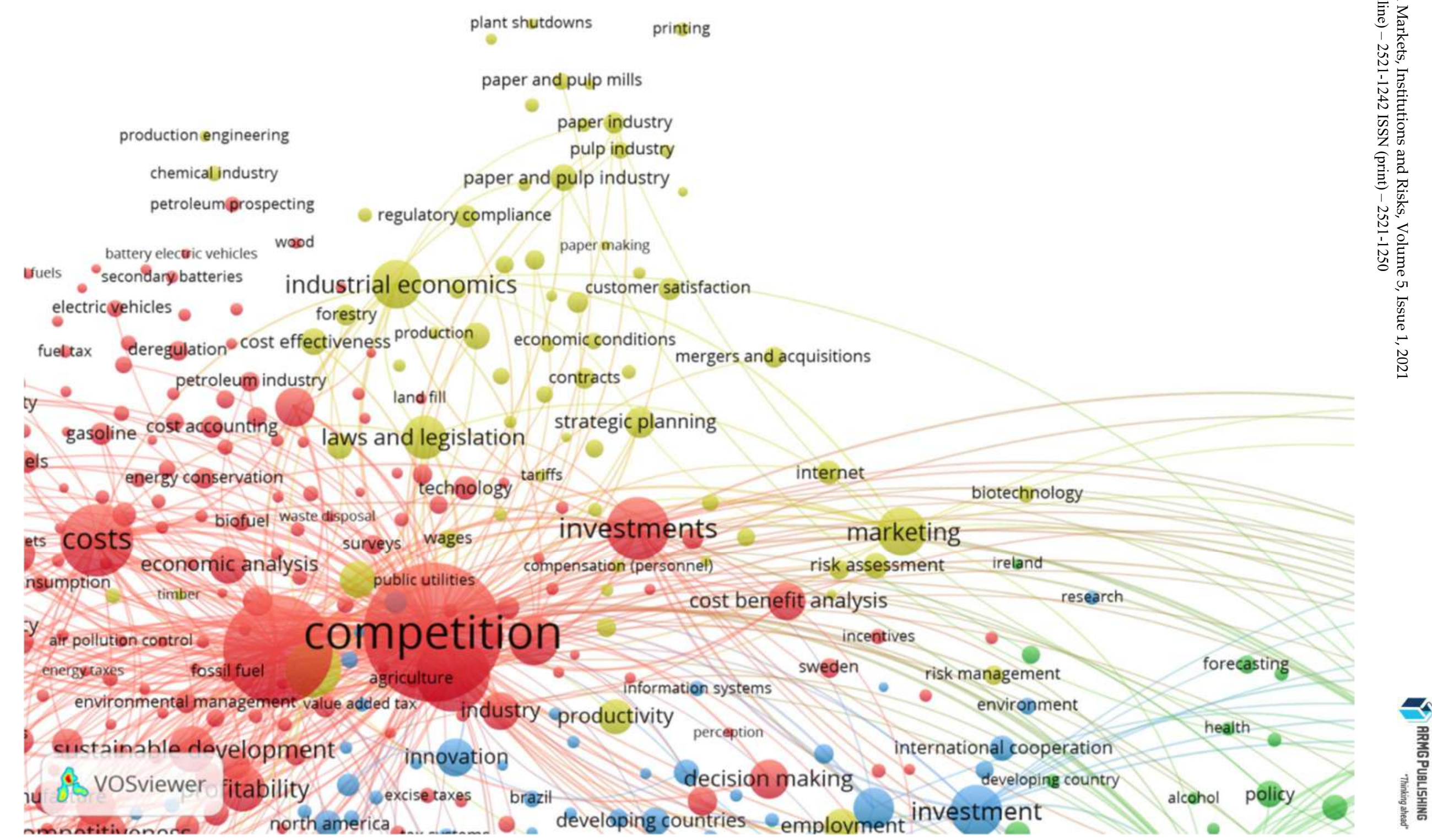

Figure 9. The network visualisation of the co-citation of the keywords on yellow cluster

Sources: Compiled by the authors using data from Scopus and WoS by VOSviewer tool. 


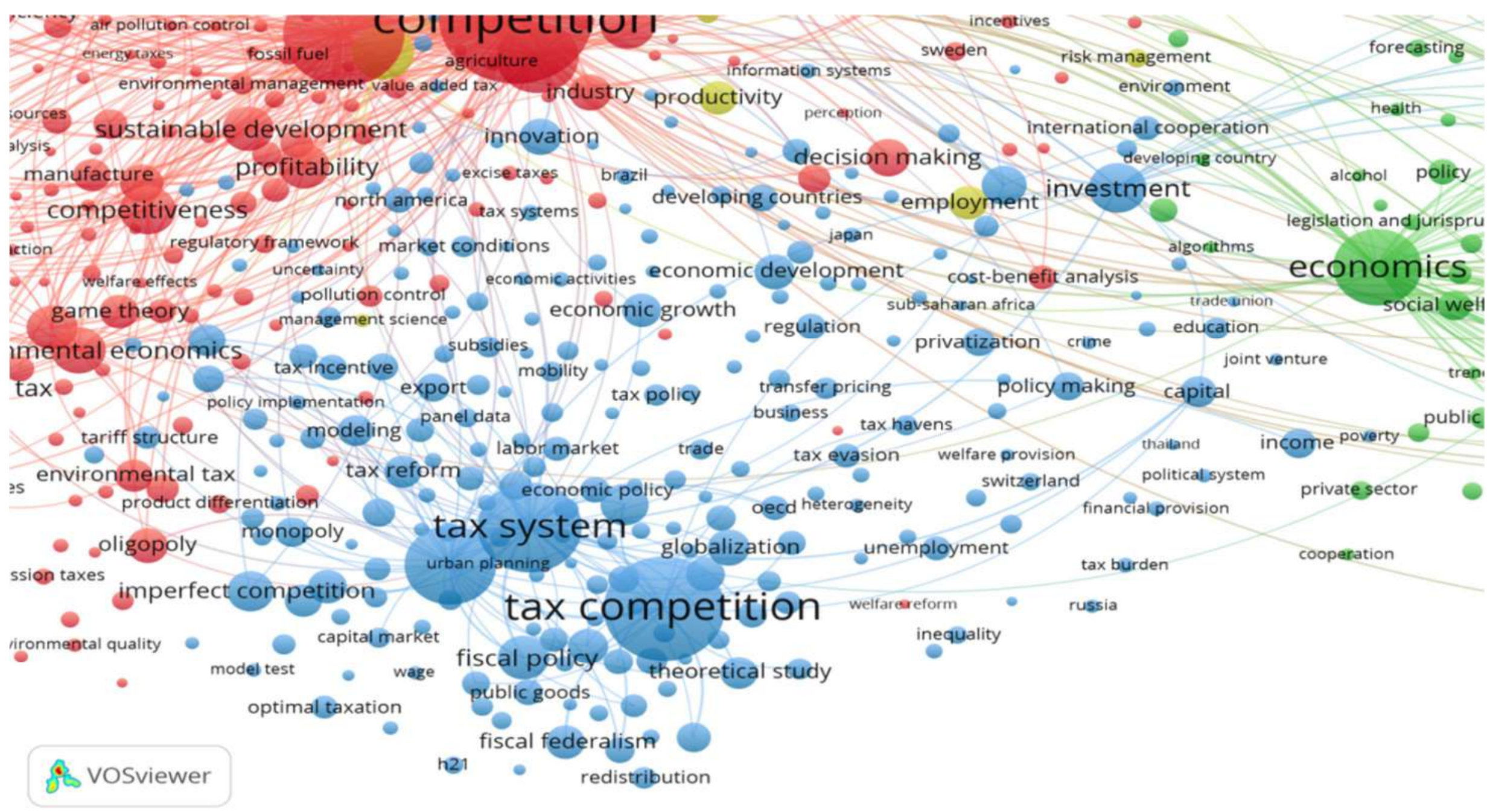

Figure 10. The network visualisation of the co-citation of the keywords on blue cluster

Sources: Compiled by the authors using data from Scopus and WoS by VOSviewer tool. 


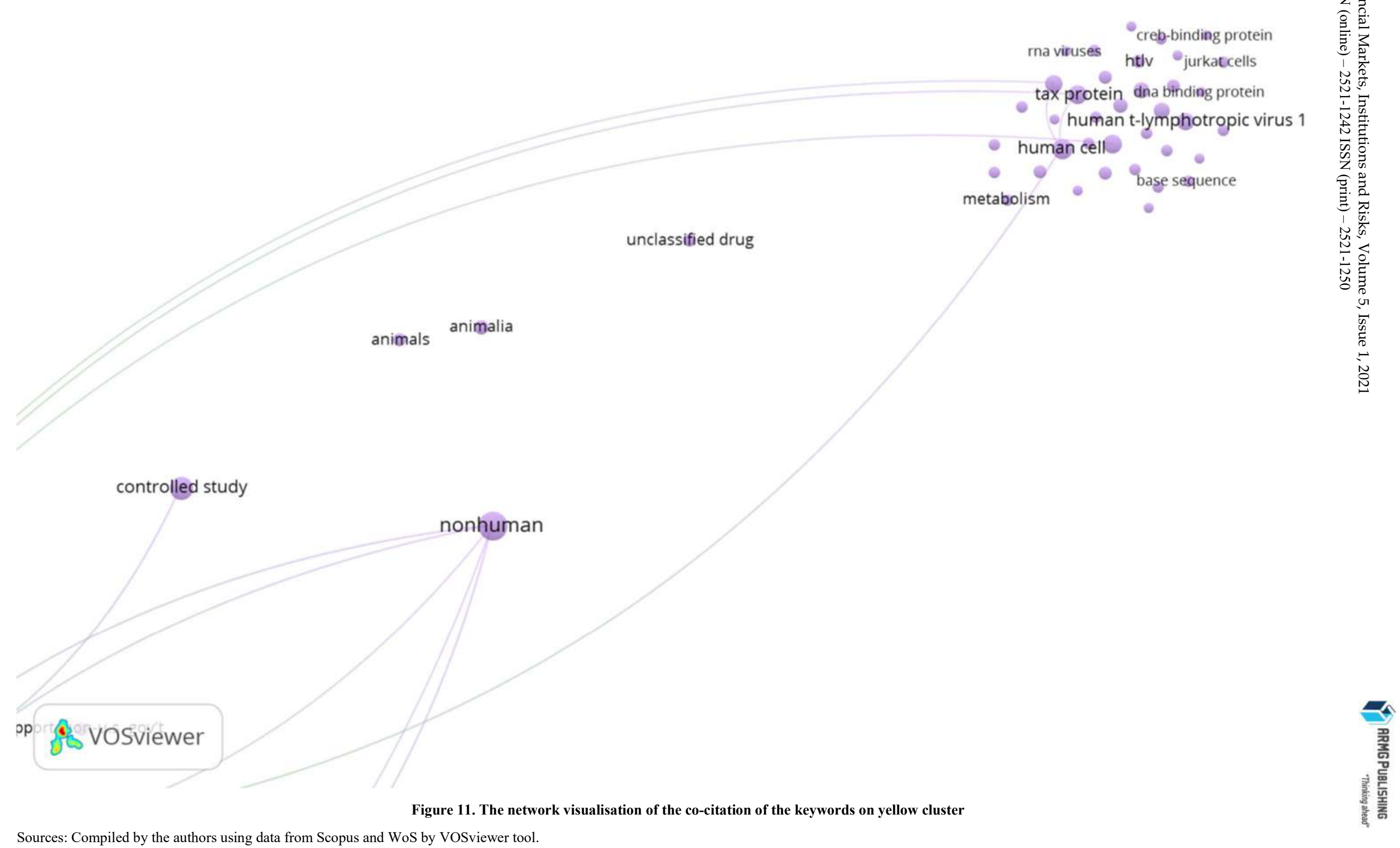

Sources: Compiled by the authors using data from Scopus and WoS by VOSviewer tool. 